Cornell Law Library

Scholarship@Cornell Law: A Digital Repository

Cornell Law Faculty Publications

Faculty Scholarship

$7-1-2002$

\title{
Bad and Not-so-Bad Arguments for Shareholder Primacy
}

Lynn A. Stout

Cornell Law School,1s483@cornell.edu

Follow this and additional works at: http://scholarship.law.cornell.edu/facpub

Part of the Corporation and Enterprise Law Commons

\section{Recommended Citation}

Stout, Lynn A., "Bad and Not-so-Bad Arguments for Shareholder Primacy" (2002). Cornell Law Faculty Publications. Paper 448. http://scholarship.law.cornell.edu/facpub/448

This Article is brought to you for free and open access by the Faculty Scholarship at Scholarship@Cornell Law: A Digital Repository. It has been accepted for inclusion in Cornell Law Faculty Publications by an authorized administrator of Scholarship@Cornell Law: A Digital Repository. For more information, please contact jmp8@cornell.edu. 


\title{
BAD AND NOT-SO-BAD ARGUMENTS FOR SHAREHOLDER PRIMACY
}

\author{
LYNN A. STOUT ${ }^{*}$
}

In 1932, the Harvard Law Review published a debate between two preeminent corporate scholars on the subject of the proper purpose of the public corporation. On one side stood the renowned Adolph A. Berle, coauthor of the classic The Modern Corporation and Private Property. ${ }^{1}$ Berle argued for what is now called "shareholder primacy"-the view that the corporation exists only to make money for its shareholders. ${ }^{2}$ According to Berle, "all powers granted to a corporation or to the management of a corporation, or to any group within the corporation... [are] at all times exercisable only for the ratable benefit of all the shareholders as their interest appears." 3

On the other side of the debate stood esteemed professor Merrick Dodd of Harvard Law School. Dodd disagreed vehemently with Berle's shareholder primacy thesis. He argued for "a view of the business corporation as an economic institution which has a social service as well as a profit-making function." ${ }^{4}$ Dodd claimed that the proper purpose of the corporation (and the proper goal of corporate managers) was not confined to making money for shareholders. It also included more secure jobs for employees, better quality products for consumers, and greater contributions to the welfare of the community as a whole.

As can be seen from Delaware Vice Chancellor Leo E. Strine's Essay in the preceding pages of this journal, the debate over the social role of the

* Professor of Law, University of California at Los Angeles School of Law. The author would like to thank William Allen, Margaret Blair, Stephen Bainbridge, Allen Ferrell, Jeffrey Gordon, Ehud Kamar, William Klein, Mark Roe, Leo E. Strine, Jr., Eric Talley, and Jack Treynor for their insightful comments on earlier drafts of this Essay.

1. adolph A. Berle \& Gardiner C. Means, The Modern Corporation and Private PROPERTY (Harvest Books, 1968) (1932).

2. See generally D. Gordon Smith, The Shareholder Primacy Norm, 23 J. CoRP. L. 277 (1998).

3. Adolph A. Berle, Corporate Powers as Powers in Trust, 44 HARv. L. Rev. 1049, 1049 (1931).

4. E. Merrick Dodd, For Whom Are Corporate Managers Trustees?, 45 HARV. L. REV. 1145, 1148 (1932). 
corporation remains unresolved. ${ }^{5}$ Does the firm exist only to increase shareholder wealth (a view that Strine dubs the "property" theory)? Or, should managers also seek to serve the interests of employees, creditors, customers, and the broader society (the "entity" view)?" After reading Strine's account of the current state of scholarly disagreement, and a similar account in another article he has coauthored, forthcoming in the University of Chicago Law Review, ${ }^{7}$ one might be tempted to throw up one's hands and conclude that academics have not lent much more insight into this question since the original Berle-Dodd debate.

In this Essay, however, I would like to suggest that we have made at least some intellectual progress over the intervening decades on the question of the proper role of the corporation. In particular, we have learned that some of the most frequently raised arguments for shareholder primacy are, not to put too fine a point on it, bad arguments. By "bad" arguments, I do not mean arguments that are somehow morally offensive or normatively unattractive. Rather, I mean arguments that are, as a positive matter, inaccurate, incorrect, and unpersuasive to the careful and neutral observer.

\section{THE SHAREHOLDER OWNERSHIP ARGUMENT FOR SHAREHOLDER PRIMACY}

Consider first what is probably the most common, and the worst, of the standard arguments for shareholder primacy. This is the argumentreally, the naked assertion-that the public corporation "belongs" to its shareholders. ${ }^{8}$ This assertion is frequently employed by commentators in the popular media and business press to justify shareholder primacy. A classic example can be found in Milton Friedman's famed 1970 essay in the New York Times, in which he argued that, because the shareholders of

5. See Leo E. Strine, Jr., The Social Responsibility of Boards of Directors and Stockholders in Change of Control Transactions: Is There Any "There" There?, 75 S. CAL. L. REv. 1169, 1170-73 (2002).

6. See William T. Allen, Our Schizophrenic Conception of the Business Corporation, 14 CARDOZO L. REV. 261, 264-66 (1992) (discussing property-entity debate).

7. William T. Allen, Jack B. Jacobs \& Leo E. Strine, Jr., The Great Takeover Debate: A Mediation on Bridging the Conceptual Divide, U. CHI. L. REV. (forthcoming 2002).

8. Although shareholder "ownership" language appears most often as a rhetorical device in the popular press, the assertion that shareholders own the firm also crops up even in contemporary corporate cases and commentary. See, e.g., Malone v. Brineat, 722 A.2d 5, 10 (Del. 1998) ("The board of directors has the legal responsibility to manage the business of a corporation for the benefit of its shareholder owners."); Lewis D. Solomon, Donald E. ShWARTZ, JefFrey D. BAUMAn, \& ElliotT J. Weiss, Corporations: LAW AND Policy, CASES AND MATERIALS 348 (4th ed. 1998) (observing that "shareholders are considered to be the corporation's ultimate owners"). 
the corporation are "the owners of the business," the only "social responsibility of business is to increase its profits."

Milton Friedman is a Nobel Prize-winning economist, but he obviously is not a lawyer. A lawyer would know that the shareholders do not, in fact, own the corporation. Rather, they own a type of corporate security commonly called "stock." As owners of stock, shareholders' rights are quite limited. For example, stockholders do not have the right to exercise control over the corporation's assets. The corporation's board of director's holds that right. ${ }^{10}$ Similarly, shareholders do not have any right to help themselves to the firm's earnings; the only time they can receive any payment directly from the corporation's coffers is when they receive a dividend, which occurs only when the directors decide to declare one. ${ }^{11}$ As a legal matter, shareholders accordingly enjoy neither direct control over the firm's assets nor direct access to them. Any influence they may have on the firm is indirect, through their influence on the board of directors. And (as Berle himself famously argued) in a public corporation with widely dispersed shareownership, shareholder influence over the board is often so diluted as to be negligible. ${ }^{12}$ Thus, while it perhaps is excusable to loosely describe a closely held firm with a single controlling shareholder as "owned" by that shareholder, it is misleading to use the language of ownership to describe the relationship between a public firm and its shareholders.

From an intellectual perspective, matters have only gotten worse for the "ownership" argument in the years since Friedman published his essay. Three years after Friedman made his argument in the New York Times, Fischer Black and Myron Scholes published their famous paper on options pricing. ${ }^{13}$ This work, which provides the foundation for modern options theory, demonstrates that it is not only misleading to say that dispersed

9. Milton Friedman, The Social Responsibility of Business Is to Increase Its Profits, N.Y. TIMES MAG., Sept. 13, 1970, at 32-33, 122-26.

10. DEL. CODE ANN. tit. $8, \S 141$ (a) (2001).

11. Id. at $\S 170(\mathrm{a})$.

12. BERLE \& MEANS, supra note 1, at 78-84. To some extent, the development of the hostile takeover has given public shareholders more power than they enjoyed in Berle's day because they can now sell en masse to a hostile bidder who can overcome the collective action problems faced by dispersed shareholders and can oust the board of directors. Given the expense and uncertainty associated with hostile takeover attempts, however, this remedy is likely to be effective only in extreme cases, leaving directors at most firms a great degree of leeway in pursuing goals other than shareholder wealth. See infra text accompanying notes $22-25$.

13. Fischer Black \& Myron Scholes, The Pricing of Options and Corporate Liabilities, $81 \mathrm{~J}$. POL. ECON. 637, 637 (1973). Myron Scholes subsequently was awarded a Nobel Prize in Economics based on his work in this paper. 
shareholders "own" a public corporation, but that it is even questionable, from an economic perspective, to say that a single controlling shareholder "owns" a closely held firm after the firm has issued debt. Options theory teaches us that once a firm has issued debt (as almost all firms do), it makes just as much sense to say that the debtholders "own" the right to the corporation's cash flow but have sold a call option to the shareholder, as it does to say that the shareholder "owns" the right to the corporation's cash flow but has bought a put option from the debtholders. ${ }^{14}$ Put differently, options theory demonstrates that bondholders and equity holders each share contingent control and bear residual risk in firms.

How, then, can one describe a publicly held corporation that has issued debt as being owned by its shareholders? The short answer is that one cannot-at least not if one is interested in accurately describing the legal and economic structure of the firm. From both a legal and an economic perspective, the claim that shareholders own the public corporation simply is empirically incorrect. The time has come to lead the "shareholder ownership" argument for shareholder primacy to the back of the barn, and to put it out of its misery.

\section{THE RESIDUAL CLAIMANTS ARGUMENT FOR SHAREHOLDER PRIMACY}

Thus, I would like to turn to what is arguably the second most frequently raised, and the second worst, of the standard arguments for shareholder primacy. This is the argument (again, one might say the naked assertion) that while shareholders may not be the owners of the corporation, they are at least its sole residual claimants.

A classic example of the use of this argument can be found in the influential work of Frank Easterbrook and Daniel Fischel of the "Chicago School" of law and economic analysis. ${ }^{15}$ Adopting the notion that the corporation can be thought of as a nexus of contracts between and among the shareholders of the firm and other corporate participants, Easterbrook and Fischel argue that the contracts entered into by nonshareholder groups such as employees, managers, and creditors are explicit contracts that entitle them to fixed payments, such as salaries and interest payments. ${ }^{16}$ In

14. See Margaret M. Blair \& Lynn A. Stout, Director Accountability and the Mediating Role of the Corporate Board, 79 WASH. U. L.Q. 403, 41 l-14 (2001) (describing implications of options theory for ownership arguments).

15. See, e.g., Frank H. Easterbrook \& Daniel R. Fischel, The Economic Structure of CORPORATE LAW 36-39 (1991).

16. Id. at 36 . 
contrast, shareholders rely on an implicit contract that entitles them to whatever remains after the firm has met its explicit obligations and paid its fixed claims. ${ }^{17}$ Thus, Easterbrook and Fischel describe shareholders as the sole "residual claimant[s]" and sole "residual risk bearers" in public firms, ${ }^{18}$ and argue that in accord with shareholders' implicit "contractual" rights, firms should be run with an eye toward maximizing shareholder wealth. ${ }^{19}$

The idea that shareholders are the sole residual claimants in firms has had a tremendous influence on contemporary scholarly thought regarding the advantages of shareholder primacy. ${ }^{20}$ Nevertheless, there remains a fundamental flaw in the residual claimants argument. Like the ownership argument, the residual claimants argument for shareholder primacy is a naked assertion, and an empirically incorrect one at that. ${ }^{21}$

To understand this point, it is essential to recognize that the only time that corporate law comes close to treating shareholders like residual claimants is when the firm is actually in bankruptcy. ${ }^{22}$ When the firm is not in bankruptcy, it is grossly misleading to suggest that the firm's shareholders are somehow entitled to-much less actually expect to receive-everything left over after the firm's explicit contractual obligations have been met. To the contrary, corporate law allows shareholders to receive payments from firms only when two conditions are met. First, the firm must be doing well enough financially (must have enough retained earnings or enough profits) to permit the directors to declare a dividend. ${ }^{23}$ Second, the directors must actually decide to declare a dividend..$^{24}$

Neither contingency can be met unless the directors want it to be met. "Retained earnings" and "profits" are accounting concepts over which directors have considerable control, because both depend not only on the

17. Id.

18. Id. at $36-37$.

19. Id. at 36 ("For most firms the expectation is that the residual risk bearers have contracted for a promise to maximize long-run profits of the firm, which in turn maximizes the value of their stock.").

20. See, e.g., Peter Coy, High Tumover, High Risk, Bus. WK., Apr. 11, 2002, at 24 ("Professors teach that in exchange for supplying companies with capital, shareholders are entitled to receive all of a corporation's wealth in excess of what's paid out to contractual claimants-a group that includes customers, bondholders, and salaried employees.").

21. See id. (noting that "theory doesn't match reality").

22. There are reasons to doubt whether shareholders are treated as residual claimants even then. See Blair \& Stout, supra note 14, at 417 n.29 (discussing shareholder rights in bankruptcy).

23. See DEL. CODE ANN. tit. 8, Sec. \$ 170(a) 2001 (describing circumstances under which directors of corporations may declare dividends).

24. See id. 
firm's earnings, but also on its expenses. If a firm is doing well in the product market, its directors have the option of allowing reported profits to increase. But they also have the option of using some or all of the firm's new wealth to raise managers' salaries, start an on-site childcare center, improve customer service, beef up retirees' pensions, or make donations to charity. Thus, even when the firm is making money hand-over-fist, it remains for the directors to decide whether and to what extent that wealth will show up in the financial statements in a form that can be paid out to shareholders. Also, even when a firm's balance sheet or earnings statement permits a dividend, directors are not required to declare one, and often they do not. It is standard operating practice among many U.S. firms to pay either small dividends or no dividends to shareholders, while retaining the lion's share of earnings for future projects. If this practice boosts stock prices, shareholders ultimately enjoy an economic benefit. That benefit, however, is indirect, and dependent on the board of directors' decisions. If the board decides to run the firm with an eye primarily to serving the interests of its executives, employees, or customers - or if they simply run it into the ground-shareholders' rights to sell their shares on the open market are of little value.

Accordingly, as a legal matter, shareholders of a public corporation are entitled to receive nothing from the firm unless and until the board of directors decides that they should receive it. Moreover, shareholders who become dissatisfied with the manner in which the board treats them have only limited practical ability to change things. A proxy battle to remove the board would be both expensive and unlikely to succeed. Similarly, while disgruntled shareholders can always hope that a takeover bidder will appear on the horizon to rescue them, takeovers are also expensive and uncertain, and rescue may come too late, if at all.

Consequently, it is grossly inaccurate as a positive matter to describe the shareholders of a public corporation as the "sole residual claimants" of a firm while that firm is a going concern. To the contrary, shareholders are only one of several groups that can be described as "residual claimants" or "residual risk bearers," in the sense that they expect to enjoy benefits (and sometimes to endure burdens) beyond those provided in their explicit contracts. When the firm is doing well, for example, employees receive raises and enjoy greater job security, managers get use of a company jet, and bondholders enjoy increased protection from corporate insolvency. Conversely, these groups suffer along with shareholders when times are bad, as employees face "reductions in force," managers are told to fly coach, and debtholders face increased risk. Directors use their control over 
the firm to reward many groups with larger slices of the corporate pie when that pie is growing, and to spread the loss among many when the pie is shrinking. A corollary to this reality is that we cannot rely on the empirically false claim that shareholders are the "sole residual claimants" of firms in order to justify shareholder primacy.

Of course, one might still argue that if shareholders are not in fact the sole residual claimants of most modern firms, that they ought to be. In other words, one might argue that while shareholders do not actually enjoy all the firm's wealth after its fixed claims have been paid, this is the very problem to be remedied by the rule of shareholder primacy. This argument treats shareholders' supposed status as sole residual claimants as a normative desideratum rather than as a positive description of the state of the world.

At this point, however, the argument for shareholder primacy becomes a tautology: corporate law ought to incorporate shareholder primacy (or so the argument goes) because shareholders ought to be the firm's sole residual claimants. This approach simply begs the fundamental question: if shareholders are not, in fact, the sole residual claimants of the public firm, why should we want them to be?

This is the question that lies at the heart of the Berle-Dodd debate, and the answer to it is not obvious. Below, I explore what may be the only good argument (meaning the only empirically sound and logically consistent argument) that can be advanced in favor of shareholder primacy. Yet to understand that argument, we must begin by considering an important argument against shareholder primacy. This is the argument based on the contracting problems associated with team production. ${ }^{25}$

\section{THE TEAM PRODUCTION ARGUMENT AGAINST SHAREHOLDER PRIMACY}

Team production analysis of the corporation begins by recognizing that corporate production often requires inputs from a number of different groups. Shareholders alone cannot make a firm-creditors, employees, managers, and even local governments often must make contributions in order for an enterprise to succeed. Why do these groups make such contributions?

25. See generally Margaret M. Blair \& Lynn A. Stout, A Team Production Theory of Corporate Law, 85 VA. L. REV. 247 (1999) (discussing team productions and its implications for corporate governance). See also Blair \& Stout, supra note 14, at 418-22 (discussing team production problem). 
To some extent, nonshareholder groups participate in and contribute to corporations because they expect to be compensated in accordance to their explicit contracts. For example, employees work, in part, because they are entitled to wages. Yet as labor economists have long argued, in a world of complexity and uncertainty, nonshareholder groups often rely on implicit contracts as well. Thus, for example, junior executives or employees might expect that if they do good work and remain loyal to the firm, and if the firm does well, they will receive not only the wages specified in their contracts but also, eventually, raises, job security, and the prospect of promotion.

Why is this expectation not reduced to writing, to a formal contract? In brief, because the resulting document would be inches thick and would raise more problems than it solved. For example, how is a court to decide how much, exactly, employees' salaries should be raised in light of the firm's profits, or to judge reliably the quality and importance of their relative contributions? ${ }^{26}$ Instead, employees, managers, creditors, and even governments often prefer to contribute to firms on the basis of bare-bones formal contracts or no formal contract at all, relying on the understanding that they will be treated considerately and allowed to share some of the bounty if the firm does well. What's more, it can be in the shareholders' interest to encourage such expectations, because those expectations encourage managers to be loyal, employees to be committed, creditors to be patient, and governments to be supportive.

This observation offers important insights into the nature of the relationship between shareholder and nonshareholder participants in corporations. First, it suggests how it is possible to increase the value of

26. To put the problem in economic terms, contracting is difficult whenever corporate production requires different parties to make contributions that become team specific (meaning that after the resources have been invested in team production, their value cannot be recovered easily except by waiting to share in the resulting profits) and whenever the output is nonseparable (meaning that it is impossible to determine exactly what portion of the output is attributable to which party's contribution). Consider the example of an entrepreneur and an investor who want to start a joint venture in which the investor provides financial capital and the entrepreneur contributes managerial skills. If the entrepreneur acquires knowledge, skills, and business contacts that are uniquely valuable to the joint venture, she will not be able to recover this investment in team-specific "human capital" by leaving and going to work for another employer. Similarly, after the investor's funds have been spent on salaries or specialized equipment, he cannot simply demand his money back. Thus both team members must wait until the venture turns a profit to recoup their investments. Furthermore, how are they to contract over how that profit will be shared? If they agree ex ante to share the wealth equally, this creates incentives for shirking. In the alternative, if they wait until the venture is a success to decide who gets what portion of the credit and the profits, they are likely to indulge in wasteful squabbling and "rentseeking." See Blair \& Stout, supra note 14, at 420 (discussing this contracting problem); Blair \& Stout, supra note 25 , at $418-22$ (discussing same). 
shareholders' economic interest in the firm (shareholders' supposedly "residual claim") without increasing the economic value of the firm itself. Put differently, a board of directors focused solely on shareholder wealth can often make shareholders better off by simply taking wealth from other corporate constituencies.

This possibility is nicely illustrated by Strine's hypothetical. Consider the dilemma faced by James Trains' board of directors. It can maximize shareholder wealth by selling the firm to the highest bidder-a bidder that would pink-slip James Train's executives, fire its rank-and-file employees, and shut down its manufacturing plants (built and maintained with the help of tax breaks and financing from state and local governments). Alternatively, for a slightly lower price, the board can sell James Trains to a reputable firm that would both keep the plants operational and retain most of the firm's employees. One cannot help but suspect that much of the additional wealth that would go into the shareholders' pockets if the firm were sold to the first bidder would be counterbalanced by monetary losses (not to mention nonmonetary losses) to the James Trains managers, employees, and the local community. Indeed, the one-time gains to the James Trains shareholders can easily be outweighed by the losses to other groups. ${ }^{27}$

Strine's hypothetical consequently demonstrates how a rule of shareholder primacy that requires the James Trains directors to sell to the highest bidder can be inefficient ex post. This potential for inefficiency becomes even greater when we consider the ex ante effects of such a rule. If the employees and managers of James Trains really believed that the firm's directors not only could sell, but were required to sell the company to the highest bidder whenever the board received an offer of even a penny

27. For example, suppose James Trains has encouraged its managers and employees to invest in firm-specific human capital through an informal understanding that so long as the firm is doing well, they will be paid a wage premium of ten percent over what they could expect to earn if forced to abandon their firm-specific investment by seeking employment elsewhere. Assume that the firm has annual sales of $\$ 120,000$ and pays annual wages totaling $\$ 110,000$, that wages are the firm's only expense, that annual profits accordingly are $\$ 10,000$, and that these profits are paid out to shareholders in the form of dividends. If a takeover bidder were to purchase the firm and then renege on the implicit understanding that the firm's employees are to be paid for their firm-specific human capital (which is valueless elsewhere), such an acquirer would be able to reduce or even eliminate the wage premium, bringing annual wage expense down from $\$ 110,000$ to as low as $\$ 100,000$. The result would be to double the shareholders' total annual dividend payments from $\$ 10,000$ to $\$ 20,000$, and also to double the value of the shareholders stock. This $100 \%$ increase in value-much larger than the premium suggested by Strine in his hypothetical-reflects not real wealth gains, but a pure wealth transfer from employees to shareholders. If the shareholders were to sell for less than a $100 \%$ premium, the end result would be that their gains are outweighed by the employees' losses. 
above market price, would the firm's executives have been as willing to commit their careers to James Trains? Would the rank-and-file have made the same effort to acquire firm-specific skills? Would state and local governments have been so willing to provide tax breaks and financing? A priori, one cannot exclude the possibility (indeed, probability) that the answer to these questions is "no." In other words, as Margaret Blair and I have argued at length elsewhere, strict shareholder primacy of the sort described by Strine in his James Trains hypothetical may inefficiently discourage nonshareholder constituents from making the types of firmspecific investments that can be essential to a company's success. ${ }^{28}$

Once one takes account of the corporation's need for firm-specific investments by many groups, and of the difficulties of drafting complete contracts under conditions of complexity and uncertainty, one cannot avoid the conclusion that shareholder primacy easily can produce results that are inefficient from both ex post and ex ante perspectives. It also becomes clear that the ideal rule for corporate directors to follow is not to require them to focus solely on maximizing shareholders' current wealth. Rather, the ideal rule of corporate governance, at least from an efficiency perspective, is to require corporate directors to maximize the sum of all the risk-adjusted returns enjoyed by all of the groups that participate in firms. ${ }^{29}$ These groups include not only shareholders, but also executives, employees, debtholders, and possibly even suppliers, consumers, and the broader community.

Because this ideal rule efficiently encourages firm-specific investment, it can be argued that it is consistent with shareholder primacy from an ex ante perspective. That is, it is in the best interests of shareholders as a class over the long run. But in the short run, it also allows directors discretion to refuse to maximize the wealth of the shareholders of a particular firm at a particular time in order to protect the extra-contractual expectations of essential nonshareholder groups. For example, it allows the James Trains directors to refuse to sell to the highest bidder. Thus, shareholders as a class may be served best not by

28. See Blair \& Stout, supra note 25, at 305.

29. More particularly, from a purely ex post perspective, the most efficient rule would be to require directors to maximize aggregate social wealth, including the wealth of groups that do not make firm-specific investments. From an ex ante team production perspective, the most efficient rule would be the one that does the best job of encouraging efficient investment in team production despite incomplete contracts. 
shareholder primacy, but by what Stephen Bainbridge has called "director primacy." 30

The superior efficiency, at least in theory, of a corporate governance rule that allows directors to take account of the interests of all of the corporations' constituents is increasingly acknowledged both in corporate scholarship $^{31}$ and in corporate case law. ${ }^{32}$ Nevertheless, it remains common practice for even sophisticated commentators to assume that shareholder primacy is somehow preferable. Why?

\section{COUNTERBALANCING TEAM PRODUCTION CONCERNS: THE AGENCY COST ARGUMENT FOR SHAREHOLDER PRIMACY}

So we come to the third, and arguably the best, of the standard arguments for shareholder primacy. This argument begins by acknowledging that, in theory, the ideal rule for corporate governance is a rule that grants directors discretion to balance the interests of all the firm's constituents. But we do not live in an ideal world. Corporate directors are only human. Accordingly, they are imperfect agents. They worry not only about the interests of the firms to which they owe fiduciary duties, but also about their own interests. As a result, they may sometimes allow selfinterest to prevail over duty, and shirk or even steal from the firm. Economists frequently refer to this problem as the problem of "agency costs." 33

30. See Stephen P. Bainbridge, Director Primacy: The Means and Ends of Corporate Governance, Nw. U. L. REV. (forthcoming 2003) (discussing how directors and not shareholders control firms). It should be noted that there are justifications for director primacy other than team production, including justifications that are consistent with shareholder wealth maximization as the normative goal of corporate governance. For example, if the stock market does not always accurately price shares, giving directors discretion to turn down a premium offer may serve shareholders' long run interest when directors can recognize that an offering price is "too low" and shareholders cannot. See id. (discussing how director primacy allows directors to hire corporate factors of production in pursuit of goal of shareholder wealth maximization).

31. See Blair \& Stout, supra note 25, at 253; G. Mitu Gulati, William A. Klein \& Eric M. Zolt, Connected Contracts, 47 UCLA L. REV. 887, 895 (2000); Frank Partnoy, Adding Derivatives to the Corporate Law Mix, 34 GA. L. REV. 599, 600, 612-16 (2000); Andrei Shleifer \& Lawrence H. Summers, Breach of Trust in Hostile Takeovers, in CORPORATE TAKEOVERS: CAUSES AND Consequences 33, 37-41 (Alan J. Auerbach ed., 1988); Thomas A. Smith, The Efficient Norm for Corporate Law: A Neotraditional Interpretation of Fiduciary Duty, 98 MiCH. L. REV. 214, 218-20 (1999).

32. For a sophisticated and instructive example, see Credit Lyonnais Bank Nederland, N.V. v. Pathe Communications Corp., 17 DEL. J. CORP. L. 1099, 1155-56 (1991), concerning the economic efficiency of allowing dircctors to take account of debtholders' intcrests.

33. It should be noted that the observation that directors are imperfect agents incorporates both the possibility that directors can be imperfect agents for shareholders (the primary focus of those who 
Agency costs can be reduced when one can monitor and measure an agent's performance. This need to measure and monitor agent performance provides the foundation for the best of the standard arguments for shareholder primacy. If we ask directors to consider the interests of all the firm's constituents, we are asking them to maximize the joint welfare function of happy consumers, secure employees, self-actualized managers, and wealthier shareholders. How are we to tell when they are doing a good job? Although it may be simple enough, at least in theory, to determine how directors' decisions affect the market price of the firm's stock and even some of its bonds, measuring the value of employee security, manager self-actualization, and consumer satisfaction (to give only a few examples) is far more difficult.

In contrast, it is easy to measure stock price. As a result, a shareholder primacy rule leaves directors with far less leeway to claim that they are doing a good job for the firm when, in fact, they are doing well mostly for themselves. As Mark Roe has put it, shareholder wealth maximization may be the best rule of corporate governance because "a stakeholder measure of managerial accountability could leave managers so much discretion that managers could easily pursue their own agenda, one that might maximize neither shareholder, employee, consumer, nor national wealth, but only their own."34

So we have learned in the decades following the Berle-Dodd debate that the issue really boils down to this: which is worse? To require directors to maximize shareholder wealth, even in cases, like Strine's James Trains, where shareholder wealth maximization is inefficient? Or to allow directors to look at the interests of nonshareholder "stakeholders," recognizing that they may use their enhanced discretion to serve themselves? Put differently, the best argument for shareholder primacy does not rest on its benefits for shareholders alone. Rather, it rests on the notion that shareholder primacy is a second-best solution that is good for all the stakeholders in the firm, because it limits what might otherwise be the runaway agency costs that might be incurred by all if directors were not held to a clear and easily observed metric of good corporate governance.

In this short Essay, I do not attempt to address which of these two economic evils-increased agency costs from a rule of director primacy or

adopt the property view of the firm) and the possibility that directors can be imperfect agents for the "firm," envisioned as an agglomeration of all the corporation's constituents (the entity view).

34. Mark J. Roe, The Shareholder Wealth Maximization Norm and Industrial Organization, 149 U. PA. L. REV. 2063, 2065 (2001). 
the ex post and ex ante inefficiencies that flow from shareholder primacyis worse. Instead, I point out that the question ultimately cannot be answered except on the basis of empirical evidence. Before we know whether social wealth is best promoted by a rule of shareholder primacy or a rule that allows directors discretion to consider other stakeholders, we must actually know the costs and the benefits that flow from each rule. We must somehow measure and weigh such matters as the importance of firmspecific human capital, the incompleteness of formal contracts, the value of a good corporate "reputation," and the risks of director self-interest. Put differently, the Berle-Dodd debate cannot be resolved by armchair theorizing.

\section{SOME EMPIRICAL EVIDENCE: WHICH RULE DO LAWMAKERS, MANAGERS, AND SHAREHOLDERS ACTUALLY CHOOSE?}

How, then, might it be resolved? Where can we search for empirical evidence on the question of whether shareholder primacy (the property model) or director primacy (the entity model) is the best approach to corporate governance?

For now, at least, I doubt that academics can provide a definitive answer. Whether the social losses from shareholder primacy outweigh the social losses from allowing greater director discretion is an extraordinarily complex question. Moreover, the answer is likely to vary from firm to firm and from one historical period to another. Case studies, and even large longitudinal studies, may be of limited value.

There is, however, another potential source of evidence to consider. This is the collective opinion of the business world itself-the opinion of the executives, directors, shareholders, and employees who actually participate in corporations, as well as the opinion of the judges and legislators who regulate them. These are the people in the trenches, the ones who experience business life as a day-to-day reality, or at least directly observe how America does business. They are also the people (as Strine reminds us) who are faced with the necessity of choosing between strategies and rules that favor shareholders, and strategies and rules that favor a broader range of corporate constituencies. ${ }^{35}$ While academics debate the relative merits of the property and the entity theory,

35. See Strine, supra note 5 , at 5 . 
businesspeople must actually choose between them, and must live with the consequences if they do not choose wisely.

Which approach do they choose? If we focus only on rhetoric, the answer is not clear. At different times and at different places, lawmakers and business leaders can be found giving lip service to both shareholder primacy and the need to consider stakeholder interests. ${ }^{36}$

Thus, it may be more useful to focus on actual behavior-what economists call "revealed preferences"- to discern the business world's beliefs about the relative merits of shareholder versus director primacy. If one adopts this approach, an interesting pattern emerges. It appears that when forced to choose, managers and shareholders alike-as well as most judges and legislators-generally opt for rules that favor director primacy over rules that favor shareholder primacy. In other words, the business world itself seems to favor the entity model.

As an example of this behavioral pattern, let us consider first the choices of lawmakers and, in particular, the choices (as opposed to the rhetoric) of the Delaware judges whose decisions affect half of all publicly traded companies. ${ }^{37}$ As Strine observes, Delaware case law generally follows the entity model. ${ }^{38}$ For example, Delaware gives directors free rein to pursue strategies that reduce shareholder wealth while benefiting other constituencies. $^{39}$ Thus, directors can use earnings to raise employees' wages rather than to declare a dividend; they can "reprice" executive stock

36. Compare Dodge v. Ford Motor Co., 170 N.W. 668, 684 (Mich. 1919) (noting that "a business corporation is organized and carried on primarily for the good profit of the stockholders") and Richard Egan, The Corporation's Responsibility to the Community, NYSE MAG., Jan./Feb., 2002, at 40 (observing that "the company that serves its community best is the one that serves its shareholders first.") with Unocal Corp. v. Mesa Petroleum Co., 493 A.2d 946, 955 (Del. 1985) (stating that among the concerns directors may consider in managing the firm is "the impact on 'constituencies' other than shareholders (i.e., creditors, customers, employees, and pcrhaps even the community generally)") and Jorma Ollila, The Business of Being Responsible, NYSE MAG., Jan./Fcb., 2002, at 34 ("Global issues of environment, health, diversity and human rights once at the periphery of management decisionmaking are fast becoming central.... [T]he clear message from rising stakeholder expectations is that companies must contribute more.").

37. Guhan Subramanian, The Influence of Antitakeover Statutes on Incorporation Choice: Evidence on the "Race" Debate and Antitakeover Overreaching, 150 U. PA. L. REV. 1795, 1801 (2002).

38. Strine, supra note 5, at 1176 (stating that exccpt when a publicly held firm is going to be merged with another private firm and acquire a controlling shareholder, "the entity model prevails"). See also Allcn et al., supra note 7, at 21 ("Delaware law inclines toward the entity model.").

39. See Paramount Communications, Inc. v. Time Inc., 571 A.2d 1140, 1150 (Del. 1989) (finding that "a board of directors . . is not under any per se duty to maximize shareholder value"). 
options even when share prices are falling; they can retroactively increase retirees' pension benefits; and they can donate corporate funds to charity. ${ }^{40}$

Such discretion seems inconsistent (to put it mildly) with shareholder wealth maximization, at least if we are focusing on the wealth of the shareholders who own stock in that particular firm at that particular time. Nevertheless, corporate law in Delaware, like corporate law elsewhere, generally allows directors to redirect wealth from shareholders to other stakeholders. In the process, courts sometimes employ the language of shareholder primacy, suggesting that actions that appear to reduce current shareholder wealth might nevertheless offer some hope of a long-run shareholder benefit. ${ }^{41}$ Such rhetoric may reflect what has been described as judicial "elision"-the tendency for courts to blur distinctions between contradictory ideas in order to decide cases while avoiding broad issues of public policy. ${ }^{42}$ Alternatively, it may reflect an intuitive recognition of the team production problem and the possibility that allowing directors discretion to consider the interests of stakeholder groups can encourage firm-specific investment, and so be in the ex ante interests of shareholders as a class, even if not always in the ex post interests of the shareholders of a particular firm. ${ }^{43}$ Whatever the explanation, the rhetoric does not change the reality. The courts have chosen between the property and the entity models of the public firm, and they have opted for the latter.

There is, of course, one notable exception to this rule-the case of Revlon, Inc. v. MacAndrews \& Forbes Holdings, Inc. ${ }^{44}$ (It is no coincidence that, in his hypothetical, Strine has chosen a situation similar to that in Revlon to illustrate the supposed clash between the property and the entity approaches in Delaware law.) In Revlon, the Delaware Supreme Court held that in an "end-game" situation where the directors of a publicly traded firm had decided to sell the firm to a company with a controlling shareholder-in brief, had decided to turn their publicly held company into a privately held one-the board had a duty to maximize shareholder wealth

40. See Smith, supra note 2 , at $279-80$ (stating that "the shareholder primacy norm is nearly irrelevant to the ordinary business decisions of modem corporations.... Outside the takeover context . . . application of the shareholder primacy norm . . is muted by the business judgment mle").

41. See Shlensky v. Wrigley, 237 N.E.2d 776, 780 (11l. App. Ct. 1968) (upholding dircctors' decisions that plaintiff alleged were harmful to shareholders, speculating that they might be in "long run" interests of firm); Revlon, lnc. v. MacAndrews \& Forbes Holdings, lnc., 506 A.2d 173, 182 (Del. 1986) ("A board may have regard for various constituencies in discharging its responsibilities, provided there are rationally related benefits accruing to the stockholders.").

42. Allen, et al., supra note 7, at 6-7 (describing judicial elision between entity and property models of corporations).

43. See supra text accompanying notes 26-32 (discussing benefits of team production).

44. Revlon, 506 A.2d at 173. 
by getting the best possible price for the firm's shares. ${ }^{45}$ Revlon thus defines the one context in which Delaware law mandates shareholder primacy.

This is a very limited context, however. Subsequent Delaware cases have dramatically reduced Revlon's significance by making clear that if the directors of the firm decide not to sell, or if they prefer a stock-for-stock exchange with another public firm, Revlon is irrelevant. ${ }^{46}$ Accordingly, directors can avoid Revlon duties when they want to. ${ }^{47}$ All this suggests that Revlon may prove to be an evolutionary dead end in corporate law, doctrinal deadwood that the courts have already pruned back and, eventually, may remove entirely.

The end result is that, if we judge their beliefs from their behavior, Delaware courts seem to have come down rather firmly on Dodd's side of the Berle-Dodd debate. This is even more true in the case of legislatures asked to address the merits of shareholder primacy. Although Delaware pruned back Revlon by case law rather than by statute, in the wake of Revlon, over thirty other states have passed "constituency" laws that expressly permit corporate directors to sacrifice shareholders' interests to serve other stakeholders. ${ }^{48}$ As a group, lawmakers seem to have a rather strong revealed preference for the entity model.

Of course, one might argue that lawmakers' revealed preferences are suspect. For example, a shareholder primacy advocate might assert that even if Delaware judges are renowned for their sophistication and knowledge of corporate matters, they still fail to choose socially optimal corporate rules because they are subject to interest group pressures and other influences that lead them to favor unduly the interests of corporate managers or corporate lawyers (the so-called "race to the bottom" thesis). ${ }^{49}$ Thus, in addition to considering the revealed preferences of lawmakers, it is

45. See Revlon, 506 A.2d at 185.

46. See, e.g., Paramount Communications, lnc, v. Time, Inc., 571 A.2d 1140, 1149-51 (Del. 1989).

47. For example, it is only because the James Train directors are considering a "cash out" merger that they have to worry about Revlon at all. Indeed, it is not uncontestably clear that Revlon would apply even in that situation. Recognizing as much, Strine has directed us to assume for the sake of the discussion that Revlon does apply. See Strine, supra note 5, at 5.

48. See Subramanian, supra note 37 , at 30 tbl.4 (listing thirty-one states as having passed otherconstituency statutes).

49. See Lucian Bebchuk, Alma Cohen \& Allen Ferrell, Does the Evidence Favor State Competition in Corporate Law, CA. L. REV. (forthcoming 2002) (manuscript at 1-4, on file with author) (describing "race-to-the-bottom" thesis); Subramanian, supra note 37, at 8-10 (same). 
perhaps more useful to consider the revealed preferences of corporate promoters and of shareholders themselves.

In assessing these preferences, it is important to distinguish between what the shareholders of a particular firm might favor ex post, and what shareholders as a class seem to prefer ex ante. In an ex post situation, such as Strine's James Trains hypothetical, one should not be surprised to hear at least some shareholders clamor for shareholder primacy. At this point in the game, many nonshareholder constituents-including, most obviously, the firm's employees and managers-have already made the firm-specific investments that promote efficient team production. Shareholders accordingly may be tempted to exploit those investments opportunistically and to line their own pockets at the expense of other stakeholders. ${ }^{50}$ Thus, once a firm is a going proposition, it is only to be expected that shareholders might sometimes adopt the position that maximizing shareholder wealth is the only proper goal of corporate governance. ${ }^{51}$

But a team production analysis of the corporation suggests that this sort of approach can be counterproductive if adopted by shareholders ex ante, when the corporation is being formed. When the corporate "contract" is first negotiated, equity investors may have a strong interest in inducing managers, employees, creditors, and even governments to commit resources to corporate production-resources that may be neither easy to recover once invested nor easy to protect by explicit contracts. One way to do this may be to place control of the firm not in the hands of the shareholders themselves, but in the hands of a board of directors that is charged with looking out for the interests of all the firm's stakeholders. Thus, director primacy may be a means for shareholders to benefit themselves by "tying their own hands" in a fashion that encourages firmspecific investments from other corporate stakeholders. ${ }^{52}$

50. See supra note 27 (providing example of this).

51. Similarly, it should not be surprising to find, as some studies have, that the adoption of antitakeover laws sometimes decreases the stock prices of firms incorporated in the state that adopts them. See Subramanian, supra note 37, at 31-33 (discussing studies of stock market reaction to antitakeover statutes). When a legislature imposes an antitakeover law on a corporation "mid-stream," it is changing the rules in the middle of the game. At that point, increasing director autonomy may not do much to encourage team production (for example, it may not do much to encourage human capital investment in firms where managers and employees made that decision years ago). Antitakeover laws may, however, work an immediate transfer of wealth from shareholders to other stakeholders, by providing the latter with even greater protection from shareholder demands than they expected to enjoy.

52. See Blair \& Stout, supra note 25 , at 273-87 (describing value of director primacy rules that allow board to serve as "mediating hierarch" of the firm). 
If this analysis is correct, we can expect to see shareholders display a revealed preference for rules that promote director primacy at early stages of a firm's development. Indeed, there is considerable evidence to suggest they do. Recent studies have concluded that states that promote director primacy by providing incumbent boards of directors with relatively strong protections against hostile takeover bids, such as Delaware, are more successful both in attracting new incorporations and in retaining the incorporations of existing firms. In contrast, firms seem to avoid incorporating or reincorporating in states with a strong shareholder primacy bias, such as California. ${ }^{53}$

Similarly, another recent study has concluded that a majority of a sample of firms that have "gone public" in recent years amended their corporate charters before doing so in order to add additional antitakeover protections (for example, a classified board system). ${ }^{54}$ This finding is almost impossible to reconcile with the claim that shareholder primacy is efficient. After all, if investors believed that the increase in agency costs associated with greater director protection from takeovers outweighed the benefits of such autonomy in terms of encouraging team production, they presumably would be less willing to buy the firm's shares. Knowing this, the firm's founders should be reluctant to adopt antitakeover provisions. Put differently, at the IPO stage when the corporation's promoters are actually "negotiating" the corporate contract with outside investors, they should have a strong preference for efficient (wealth-maximizing) rules. It would seem that both shareholders and promoters prefer director primacy.

This conclusion is bolstered by a final and related observation: Delaware corporate law, like most corporate law, is an enabling system. This means that most of the rules provided by Delaware are default rules that corporate promoters are free to modify through charter and bylaw provisions. Thus, there is nothing to prevent a promoter who thinks that shareholders actually want shareholder primacy from providing in the firm's articles of incorporation that Revlon duties apply to all the board's decisions, not just to cash-out mergers. Put more bluntly, there is nothing

53. See, e.g., LuCian Bebchuk \& Alma Cohen, Olin Center, Firms' Decisions Where to INCORPORATE 10-11 (Feb., 2002) (unpublished manuscript, on file with The Southern California Law School); Bebchuk, Cohen \& Ferrell, supra note 49, at 34-40; Subramanian, supra note 37, at 52-53.

54. See Robert Daines \& Michael Klausner, Do IPO Charters Maximize Firm Value? Antitakeover Protection in IPOs, 17 J.L. ECON. \& ORG. 83, 95-97 (2001). 
to stop corporate promoters from expressly providing for shareholder wealth maximization as a corporate goal in the firm's charter. ${ }^{55}$

If shareholders really valued shareholder primacy rules, one would think at least a few promoters might have thought of inserting such provisions in the corporate charter at the IPO stage. However, I have never heard of, much less seen, such a charter provision. I suspect the reason may be that promoters and investors alike understand that if the firm did mandate shareholder primacy in its charter, it would find it far more difficult to attract qualified, motivated, and loyal employees, managers, and even creditors. Perhaps this suspicion is incorrect-perhaps firms that go public do not put shareholder primacy provisions into their charters simply because it has never occurred to anyone that there might be value in doing so. But if shareholder primacy is indeed clearly the optimal rule of corporate governance, as many academics believe, it seems curious that corporate participants, including shareholders themselves, have overlooked this possibility.

This is not to suggest that such observations alone provide proof that shareholder primacy is inefficient. More work remains to be done before one can reach a sound empirical conclusion about whether the agency costs associated with director primacy are greater or less than the cost of lost opportunities for team production that flow from a shareholder primacy regime. But at a minimum, the findings - that firms seem to prefer to incorporate in states with relatively strong antitakeover laws, that they often insert antitakeover provisions into their charters when going public, and that charter provisions mandating shareholder primacy are notably missing —ought to be enough to make careful and dispassionate observers suspicious. The claim that shareholder primacy is needed to control agency costs is clearly a better argument for the property model of the corporation than either the shareholder ownership argument or the residual claimants argument. Still, without some evidence that shareholders themselves desire shareholder primacy-not only ex post when they can extract wealth from other corporate stakeholders, but also ex ante when they need stakeholders cooperation and investment-it is perhaps a bit of a reach to describe the agency cost argument as a truly "good" argument for shareholder primacy. "Not-so-bad" may be a more precise description.

55. See DEL. CODE ANN. tit. 8, § 102(b) (2001) (allowing firms to include in their charters "[a]ny provision for the management of the business," including "any provision creating, defining, limiting and regulating the powers of the corporation, the directors, and the stockholders"). 


\section{CONCLUSION}

Since the days of Berle and Dodd, scholars, commentators, lawmakers, and businesspeople have debated the purpose of the corporation. Does it exist only to create wealth for shareholders (the property model)? Or does good corporate governance demand that a firm's board of directors also consider the interests of other stakeholders, including managers, employees, creditors, and the broader society (the entity model)?

If the debate remains unresolved, at least there has been some progress in our understanding of it. In particular, we have learned that two of the most commonly advanced arguments for shareholder primacy-the argument that the shareholders "own" the firm and the argument that shareholders are the firm's sole residual claimants - are bad arguments, in the sense that they are built on empirical claims that are demonstrably false. There is a third argument for shareholder primacy that is much more reasonable. This is the argument that shareholder primacy is necessary to protect not just shareholders, but all the firm's stakeholders, by reducing the runaway agency costs that would be incurred if corporate directors were invited to consider the interests of both shareholders and other stakeholders as well. Put differently, shareholders and stakeholders alike are thought to be made better off by a rule that prevents directors from pursuing strategies that reduce share price whenever this can be rationalized as somehow serving the often-intangible interests of other constituencies.

There is one rather awkward and rather significant difficulty with this argument, however. Corporate law, in fact, does allow directors to pursue strategies that reduce share price whenever this can be rationalized as somehow serving the often-intangible interests of other constituencies. Put differently, outside the limited context of Revlon, corporate law follows the entity model. Moreover, both corporate managers and shareholders show little interest in departing from that model, even though the enabling nature of corporate law allows them to do so.

Berle himself eventually recognized this reality of modern business life. ${ }^{56}$ More than two decades after he first crossed words with the Harvard professor, Berle published The 20th Century Capitalist Revolution. ${ }^{57}$ In

56. Indeed, as Jack Treynor has pointed out, despite the impression given by his argument in the Harvard Law Review, Berle's contemporaneous writings with Gardiner Means gave a far more agnostic view of whether the shareholder primacy view could or should eventually prevail in the modern corporation. Jack L. Treynor, Samizdat: The Value of Control, FIN. ANALYSTS J. 6 (July-Aug. 1993).

57. Adolphe A. Berle, The 20Th Century Capitalist Revolution (1954). 
that book, Berle observed that corporate law had evolved in a direction that allowed directors almost total discretion over how to use corporate assets, including even giving them away to charity. He then offered his own view of the outcome of the Berle-Dodd debate:

Twenty years ago, the writer had a controversy with the late Professor E. Merrick Dodd, of Harvard Law School, the writer holding that corporate powers were powers in trust for shareholders while Professor Dodd argued that these powers were held in trust for the entire community. The argument has been settled (at least for the time being) squarely in favor of Professor Dodd's contention. ${ }^{58}$

Half a century after Berle's concession, academics continue to argue the merits of the property versus the entity model of the firm. The business world continues to prefer the entity model of the firm.

58. Id. at 169. 
